\title{
DAMPAK PENJATUHAN PIDANA KORUPSI BAGI PEGAWAI NEGERI YANG SEDANG MENJALANKAN TUGAS ADMINISTRASI NEGARA $^{1}$
}

\author{
M. Agus Santoso \\ Fakultas Hukum Universitas Widya Gama Mahakam \\ Jl. M. Yamin No. 30-31 Samarinda
}

\begin{abstract}
Corruption in Indonesia has leaded big impact and be a fundamental problem. It even has been setted in mind, that's why it needs serious preventing action from all sides. In general corruption is done by goverment officers who are doing administration duty of goverment, because of intentional factor to misuse the anthonty caretessness and even lack of accuration can be decived by law of criminal of corruption. Corruption case that has been happened was the case of area liberation for the guard-house of PLN in Samarinda that caused several public administration officers or civil servants are affected by criminal corruption punishment so that civil servants should be careful in performing their duty and not violate the laws, the effect for another government officers are afraid in doing their duty/task.
\end{abstract}

Keywords : Corruption, civil servant, public administration task.

\section{Intisari}

Perbuatan korupsi di Indonesia selama ini telah membawa dampak yang sangat besar dan merupakan masalah mendasar bahkan telah mengakar sedemikian rupa, sehingga pemberantasannya perlu keseriusan dari semua pihak. Pada umumnya korupsi dilakukan oleh pegawai negeri yang sedang menjalankan tugas administrasi negara, karena unsur sengaja, menyalah gunakan wewenang, kelalaian dan bahkan kurang cermat bisa terjerat dijatuhi hukuman pidana korupsi. Pengalaman yang telah terjadi adalah kasus pembebasan lahan untuk kepentingan pembangunan gardu PLN di Samarinda, yang mengakibatkan beberapa pejabat administrasi kota Samarinda dijatuhi pidana korupsi, sehingga pejabat administrasi negara harus super hati-hati dalam mengemban tugas administrasi negara, akibatnya terhadap pegawai negeri yang lain ketakutan dalam menjalankan tugasnya.

Kata kunci : Korupsi, pegawai negeri, tugas administrasi negara.

${ }^{1}$ Naskah diterima: 6 Desember 2010, revisi: 25 Maret 2011 


\section{A. PENDAHULUAN}

Benderang reformasi berkumandang di Indonesia sekitar tahun 1988, sejak saat itu pulalah perang melawan korupsi mulai ramai disuarakan oleh berbagai pihak, karena pada saat orde baru korupsi hampir tidak dapat tersentuh oleh peradilan, sehingga menjadi agenda penting dalam menjalankan pemerintahan saat ini. Berdasarkan hasil survey, korupsi di Indonesia masih berada ditingkat atas, karena itu sudah menjadi permasalahan yang mengakar sedemikan rupa sehingga sulit untuk diberantas. Hasil survey lembaga konsultan PERC yang berbasis di Hongkong menyatakan bahwa Indonesia merupakan negara yang paling korup di antara 12 negara Asia. Disinyalir korupsi di Indonesia bukan saja terjadi di tingkat pemerintah pusat, tetapi sudah menjalar sampai ke tingkat pemerintah daerah bahkan elemen pemerintahan yang paling kecil. Sejak berlakunya Undang-Undang Nomor 22 Tahun 1999, tentang Pemerintahan Daerah, kemudian dirubah dengan Undang-Undang Nomor 32, Tahun 2004, tentang Pemerintahan Daerah, kasus korupsi di Indonesia terus meningkat sehingga pemberantasan korupsi menjadi agenda yang sangat pentung bagi pemerintahan, namun hal itu tergantung bagaimana komitmen bersama, terutama para pemegang kekuasaan tertinggi negara.
Kekuasaan tertinggi pemerintah di Indonesia dijalankan oleh Presiden dan Wakil Presiden. Pasal 4 ayat (1) UUD 1945, menyatakan: "Presiden Republik Indonesia memegang kekuasaan pemerintahan menurut Undang-Undang Dasar." Pasal 4 ayat (2) UUD 1945 berbunyi: "Dalam melakukan kewajibannya Presiden dibantu oleh satu orang Wakil Presiden." Wilayah Indonesia begitu luas, terbagi dalam berbagai pulau dan kepulauan, maka dalam menjalankan pemerintahan, Presiden dan Wakil Presiden tidak mungkin mengatur dan mengurus sendiri seluruh pemerintahannya, oleh karena itu harus ada pelimpahan wewenang dalam menjalankan pemerintahan di daerah. Pasal 18 ayat (1) UUD 1945 berbunyi: "Negara Kesatuan Rapublik Indonesia dibagi atas daerah-daerah provinsi dan daerah provinsi itu dibagi atas kabupaten dan kota, yang tiap-tiap provinsi, kabupaten, dan kota itu mempunyai pemerintahan daerah, yang diatur dengan Undang-Undang." Pasal 18 ayat (2) UUD 1945 menyebutkan bahwa: "Pemerintahan daerah provinsi, daerah kabupaten, dan kota mengatur dan mengurus sendiri urusan pemerintahan menurut asas otonomi dan tugas pembantuan."

Pasal 1 ayat (2) Undang-Undang Nomor 32 Tahun 2004, tentang Pemerintahan Daerah menyatakan bahwa : "Pemerintahan daerah adalah penyelenggara urusan pemerintahan 
oleh pemerintah daerah dan DPRD menurut asas otonomi dan tugas pembantuan dengan prinsip otonomi seluas-luasnya dalam sistem dan prinsip Negara Kesatuan Republik Indonesia, sebagaimana dimaksud dalam Undang-Undang Dasar Negara Republik Indonesia Tahun 1945.” Pasal 1 ayat (3) Undang-Undang Nomor 32 Tahun 2004, tentang Pemerintahan Daerah menyebutkan bahwa : "Pemerintah daerah adalah Gubernur, Bupati, atau Walikota, dan perangkat daerah sebagai unsur penyelenggara pemerintahan daerah." Sedangkan Presiden dan Wakil Presiden, Gubernur dan Wakil Gubernur, Bupati dan Wakil Bupati, Walikota dan Wakil Walikota adalah pejabat administrasi negara atau pejabat publik yang menjalankan tugas kebijakan publik. Kebijakan publik adalah kewenangan pemerintah dalam pembuatan suatu kebijakan yang digunakan kedalam perangkat peraturan hukum, kebijakan tersebut bertujuan untuk menyerap dinamika sosial dalam masyarakat, yang akan dijadikan acuan perumusan kebijakan agar tercipta hubungan sosial yang harmonis. $^{2}$

Pejabat administrasi yang menjalankan semua tugas pemerintahan berupa pelayanan dan sebagainya disebut proses birokrasi, yaitu merupakan struktur organisasi di sektor pemerintahan, yang memilki ruang lingkup tugas-tugas sangat luas serta memerlukan organisasi besar dengan sumber daya manusia yang besar pula jumlahnya. ${ }^{3}$ Birokrasi adalah keseluruhan organisasi pemerintah, yang menjalankan tugastugas negara dalam berbagai unit organisasi pemerintah dibawah departemen dan lembaga-lembaga non departeman, baik di pusat maupun di daerah, seperti ditingkat provinsi, kabupaten, kecamatan, maupun desa atau kelurahan. ${ }^{4}$ Dari uraian diatas dapat dikatakan bahwa birokrasi merupakan lembaga pemerintah yang menjalankan tugas pelayanan pemerintahan baik ditingkat pemerintah pusat maupun ditingkat pemerintah daerah, yang merupakan tugas administrasi negara, sedangkan ruang lingkup Administrasi Negara atau Administrasi publik meliputi 1). Kbijakan, 2). Organisasi, 3). Manajemen, 4). Moral dan etika, 5). Lingkungan, dan 6). Akuntbilitas. ${ }^{5}$

Administrasi Negara dalam arti luas didefinisikan sebagai kegiatan negara dalam melaksanakan kekuasaan politiknya, sedangkan dalam arti sempit Administrasi Negara

\footnotetext{
${ }^{2}$ Chaizi Nasucha, Reformasi Administrasi Publik: Teori dan Praktek, Grasindo, Jakarta, 2004, hal : 37

3 J.B. Kristiadi, Administrasi/Manajemen Pembangunan, LAN Jakarta, 1994, hal : 93

${ }^{4}$ Priyo Budi Santoso, Birokrasi Pemerintahan Orde Baru; Perspektif kultur dan Struktural, Grafindo Persada, Jakarta, 1997, hal : 7

${ }^{5}$ Yaremis T Keban, Enam Dimensi Strategis Administrasi Publik : Konsep, teori dan Isu, Gava Media, Jakarta, 2004, hal : 10
} 
didefinisikan sebagai kegiatan badan ekskutif dalam penyelenggaraan pemerintahan. ${ }^{6}$ Tugas administrasi adalah merumuskan kebijakan pelaksanaan dari kebijakan politik yang telah ditetapkan sebelumnya, sedangkan yang melaksanakan kebijakan politik dalam pelaksanaan ini adalah pejabat pemerintah profesional, yang disebut administrator profesi dan pada umumnya adalah pejabat-pejabat pemerintah yang bekerja pada suatu departemen tehnis yang secara fungsional mempunyai keahlian pada substansi tehnisnya masing-masing. ${ }^{7}$ Wewenang untuk merumuskan peraturan kebijakan merupakan pengaturan (regeling), sedangkan wewenang untuk menetapkan kebijakan adalah penetapan (beschikking), kemudian wewenang untuk melaksanakan kebijakan merupakan wewenang pengurusan atau melaksanakan (bestuur).

Pasal 20 ayat (1) UndangUndang Nomor 32 Tahun 2004, tentang Pemerintahan Daerah, menyebutkan mengenai asas penyelenggaraan pemerintahan, yaitu : (a). asas kepastian hukum; (b). asas tertib penyelenggara negara; (c). asas kepentingan umum; (d). asas keterbukaan; (e). asas proporsionalitas; (f). asas profesionalitas; (g). asas akuntabilitas; (h). asas efisien; dan (i). asas efektifitas. Disamping asas-asas tersebut dalam menjalankan pemerintahan harus berorientasi pada pemerintahan yang baik (good governance) dan pemerintahan yang bersih (clean goverment), yang dijabarkan lebih lanjut yaitu pemerintahan yang bersih dan bebas dari Korupsi, Kolusi, dan Nepotisme $(\mathrm{KKN})$.

Undang-Undang Nomor 28 Tahun 1999, tentang Penyelenggaraan Pemerintah yang Bersih dari Korupsi, Kolusi dan Nepotisme (KKN) sebagai landasan hukum, menghendaki perilaku aparat Pemerintahan yang baik tidak melakukan korupsi, kolusi dan nepotisme. Sebagai pribadi yang baik adalah yang berpengalaman, berbakat dan minat kepentingan aparat pemerintahannya harus baik, kemudian lingkungan kerjanya juga baik, lingkungan kerja yang bersih dari korupsi, kolusi dan nepotisme, sebab lingkungan kerja yang buruk akan mempengaruhi perilaku aparat pemerintahan. Alam pikir manusia dalam menjalankan aktifitas kerja sering dipengaruhi oleh suasana disekitarnya (milieunya). Alam pikiran itulah yang harus dibersihkan agar tidak berpikir kearah pikiran korupsi, kolusi dan nepotisme yang sudah merajalela di Indonesia, sehingga

\footnotetext{
${ }^{6}$ Siswanto Sunarno, Hukum Pemerintahan Daerah di Indonesia, Sinar Grafika, Jakarta, 2008, hal : 51 ${ }^{7}$ Ibid
} 
penanganannya diperlukan keseriusan dari semua pihak termasuk merubah budaya serta moral agar tidak selalu berpikir korupsi.

Tindak pidana korupsi di Indonesia sudah menjadi persoalan yang amat penting dan mendasar bahkan telah mengakar sedemikian rupa, oleh karena itu penanganannya memerlukan perhatian khusus dari semua pihak yang cinta akan bangsa yang merdeka ini. Tindak pidana korupsi telah menimbulkan kerusakan di berbagai kehidupan masyarakat, bangsa dan negara Indonesia, sehingga u p a y a e c e gah a $\mathrm{d}$ a n pemberantasannya perlu dilakukan secara terus menerus dan berkesinambungan yang menuntut peran serta dari semua pihak serta peningkatan kapasitas sumber daya manusia dan sumber daya lainnya. Dari semua itu yang terpenting adalah mengembangkan budaya dan kesadaran, sikap dan perilaku masyarakat anti korupsi, karena tindak pidana korupsi bukan saja akan berdampak merugian perekonomian nasional tetapi akan mengancam kerusakan moral bangsa dan sebagainya.

Tindak pidana korupsi di Indonesia terlihat semakin lama semakin meluas, disinyalir terjadi di semua bidang dan sektor pembangunan, apalagi setelah ditetapkannya pelaksanaan Undang-
Undang Nomor 22 Tahun 1999, tentang Pemerintahan Daerah, kemudian diperbaharui dengan Undang-Undang Nomor 32 Tahun 2004, tentang Pemerintahan Daerah, tindak pidana korupsi bukan saja terjadi ditingkat pusat tetapi juga sudah pada tingkat daerah bahkan menembus pemerintahan yang paling kecil di daerah, hingga sampai pada para pengusaha swasta. Pemberantasan tindak pidana korupsi yang dilakukan sudah semakin serius pula, disamping sudah ada Undang-Undang yang mengatur tentang tindak pidana korupsi, juga telah diundangkan adanya pengadilan tindak pidana korupsi yang akan berada di seluruh Indonesia, yaitu Undang-Undang Nomor 46 Tahun 2009, tentang Pengadilan Tindak Pidana Korupsi (TIPIKOR).

Berdasarkan ketentuan Pasal 2 ayat (1) Undang-Undang Nomor 31 Tahun 1999, tentang Pemberantasan Tindak Pidana Korupsi, sebagaimana yang diubah dengan Undang-Undang Nomor 20 Tahun 2001, korupsi adalah : "Setiap orang secara melawan hukum dengan maksud memperkaya diri sendiri atau orang lain atau suatu korporasi yang dapat merugikan keuangan negara atau perekonomian negara, dipidana dengan pidana penjara seumur hidup atau pidana penjara paling singkat 4 (empat) tahun dan paling lama 20 (dua puluh) tahun dan denda paling sedikit Rp.200.000.000,- 
(dua ratus juta rupiah) dan paling banyak Rp.1.000.000.000,- (satu milyar rupiah)." Pasal 3 (tiga) UndangUndang yang sama menyebutkan bahwa : "Setiap orang yang dengan tujuan menguntungkan diri sendiri atau orang lain atau suatu korporasi, menyalahgunakan kewenangan, kesempatan atau sarana yang ada padanya karena jabatan atau kedudukan yang dapat merugikan keuangan negara atau perekonomian negara, dipidana dengan pidana penjara seumur hidup atau pidana penjara paling singkat 1 (satu) tahun dan paling lama 20 (dua puluh) tahun dan atau denda paling sedikit Rp. 50.000.000,(lima pulih juta rupuah) dan paling banyak Rp. 1.000.000.000,- (satu milyar rupiah)."

Pengertian korupsi menurut Undang-Undang tersebut adalah sebagai perilaku merugikan keuangan negara yang dilakukan oleh seseorang atau beberapa orang atau pihak, apakah seorang birokrasi atau pengawai negeri, swasta, maupun masyarakat luas, asalkan terdapat unsur-unsur: (a). secara melawan hukum; (b). memperkaya diri sendiri atau orang lain; (c). dapat merugikan keuangan negara; Atau (a). dengan tujuan menguntungkan diri sendiri atau orang lain; (b). menyalahgunakan wewenang, kesempatan atau sarana yang ada padanya karena jabatannya; (c). merugikan keuangan negara. Selain itu pada dasarnya tindak pidana korupsi t e r m a s u k p n y u a a n, penggelapan/pencurian, penipuan dan pemerasan, kesemua bentuk itu di dalam praktek sering kali terjadi saling mempengaruhi sampai di sidang pengadilan yang disebut mafia kasus (markus).

Hal yang menarik untuk dikaji, bukan masalah bagaimana pertimbangan hukum majelis hakim tetapi mengenai pola pejabat administrasi yang menjalankan tugas administrasi agar berhati-hati. Hal ini supaya tidak melanggar hukum sehingga tidak dijatuhi hukuman pidana korupsi, bukan saja disengaja tetapi termasuk menyalahgunakan wewenang yang tidak disengajapun bisa berakibat menimbulkan pelanggaran hukum dan dijatuhi hukuman pidana korupsi. Disamping itu juga mengenai dampak yang timbul terhadap penjatuhan pidana korupsi bagi pegawai negeri atau pejabat administrasi yang sedang menjalankan tugasnya. Maka dapat dirumuskan beberapa pertanyaan. Pertama, mengapa pejabat publik dalam menjalankan tugas administrasi negara bisa dijatuhi pidana korupsi? Kedua, bagaimana dampak penjatuhan pidana korupsi bagi pegawai negeri yang

\footnotetext{
${ }^{8}$ Tribun Kaltim, Sabtu 16 Oktober 2010, hal :1.

${ }^{9}$ C.F.G. Sunaryati Hartono, Penelitian hukum di Indonesia pada akhir abad ke-20. Alumni, Bandung, 1994, hal : 151
} 


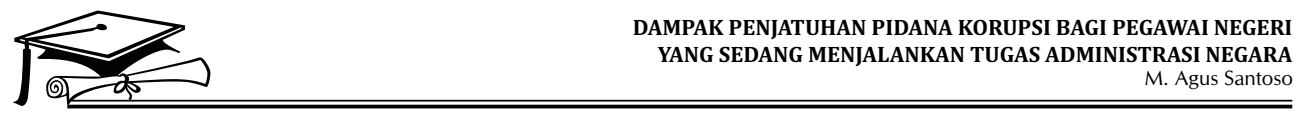

sedang menjalankan tugas administrasi negara?

Kajian ini secara praktis bertujuan untuk menemukan data-data dan jawaban atas permasalahan yang diketengahkan. Yaitu pertama, untuk mengetahui mengapa menjalankan tugas administrasi negara bisa dijatuhi pidana korupsi. Dan kedua, bagaimana dampak penjatuhan pidana korupsi bagi pegawai negeri yang sedang menjalankan tugas adminstrasi negara.

\section{B. METODE PENELITIAN}

Penelitian ini merupakan penelitian hukum normatif, bahwa penelitian hukum normatif yang juga biasa disebut penelitian hukum doktrinal biasanya dipergunakan sumber-sumber data sekunder saja yaitu peraturan-peraturan perundangan, keputusan-keputusan pengadilan, teori hukum, dan pendapat para sarjana terkemuka. ${ }^{9}$ Pertimbangan memilih penelitian hukum normatif karena bahan utama penelitian ini adalah berbagai Undang-Undang yang berkaitan dengan tindak pidana korupsi dan administrasi negara, serta putusan Pengadilan Negeri Samarinda No.: 620/Pid.B/2010/PN Smda, tanggal 23 Nopember 2010, yang dipadu dengan pendapat para sarjana terkemuka dari berbagai literatur serta dilengkapi dengan hasil wawancara sebagai bahan pendukung.

Data yang dikumpulkan terutama melalui studi dokumen dan bahan pustaka, diperlukan juga data lapangan (field research) melalui wawancara dengan beberapa pegawai negeri di Kota Samarinda yang merupakan bahan pendukung, sedangkan analisis data yang digunakan adalah analisis kualitatif, yaitu analisis yang menguraikan data penelitian menjadi komponen-komponen melalui rangkaian kata-kata, analisis kualitatif lebih menekankan terhadap kualitas data daripada kuatitas data itu sendiri dalam rangka mengungkapkan karakternya yang khas, pengertian konteks sosialnya, dan realisasi satu sama lain, kemudian menganalisisnya secara diskriptif dan interpretasi.

\section{TINJAUAN PUSTAKA}

Penelitian ini berjudul: Dampak Penjatuhan Pidana korupsi Bagi Pegawai Negeri Yang Sedang Menjalankan Tugas Adminstrasi Negara. Korupsi berasal dari bahasa latin, yaitu corruption atau corruptus. Corruption berasal dari kata corrumpere, suatu kata latin yang lebih tua. Dari bahasa latin itulah turun ke banyak bahasa Eropa seperti Inggris yaitu corruption, corrupt; Perancis yaitu corruption; dan Belanda yaitu corruptie, korruptie. Dari bahasa Belanda inilah kata itu turun ke bahasa Indonesia yaitu korupsi. ${ }^{10}$ Kemudian dalam kamus bahasa Indonesia, korupsi berasal dari kata "korup" dapat diartikan sebagai : "busuk; buruk; suka menilap barang atau sesuatu untuk kepetingan pribadi; Korupsi berarti penyelewengan atau penggelapan harta milik negara atau perusahaan, ${ }^{11}$ Sedangkan dalam kamus hukum,

\footnotetext{
${ }^{10}$ A. Hamzah, Pemberantasan Korupsi, Raja Grafindo Persada, Jakarta, 2005, hal : 4

${ }^{11}$ Eko Hadi Wiyono, Kamus Bahasa Indonesia Lengkap, Palanta, Jakarta, 2007, hal : 340
} 
korupsi adalah "buruk; rusak; suka m e n e rim a u a g s o g o k ; menyelewengkan uang/barang milik perusahaan negara; menerima uang dengan menggunakan jabatannya untuk kepentingan pribadi atau penyelewengan atau penggelapan uang negara atau perusahaan sebagai tempat seseorang bekerja untuk keuntungan pribadi atau orang lain.",12

Mengenai definisi korupsi, Kartini Kartono memberikan batasan sebagai berikut: "Tingkah laku individu yang menggunakan wewenang dan jabatan guna mengeduk keuntungan pribadi, dan atau merugikan kepentingan umum dan Negara."13 Juniadi Suwartojo mengatakan: "Korupsi ialah tingkah laku atau tindakan seseorang atau lebih yang melanggar norma-norma yang berlaku dengan menggunakan dan/atau menyalahgunakan kekuasaan atau kesempatan melalui proses pengadaan, penetapan pungutan penerimaan atau pemberian fasilitas atau jasa lainnya yang dilakukan pada kegiatan penerimaan dan/atau pengeluaran uang atau kekayaan, penyimpanan atau kekayaan serta dalam perizinan dan/atau jasa lainnya dengan tujuan keuntungan pribadi atau golongannya sehingga langsung atau tidak langsung merugikan kepentingan dan/atau keuangan negara/masyarakat."14 Sementara menurut Brooks dalam Klitgaard memberikan pengertian korupsi yaitu "Dengan sengaja melakukan kesalahan atau malalaikan tugas yang diketahui sebagai kewajiban, atau tanpa hak menggunakan kekuasaan, dengan tujuan memperoleh keuntungan yang sedikit banyak bersifat pribadi.",

Sedangkan yang dimaksud tindak pidana korupsi menurut Pasal 2 ayat (1) Undang-Undang Nomor 31 Tahun 1999, tentang Pemberantasan Tindak Pidana Korupsi sebagaimana diubah dengan Undang-Undang Nomor 20 Tahun 2001, adalah "Setiap orang yang secara melawan hukum melakukan perbuatan memperkaya diri sendiri atau orang lain atau suatu korporasi yang dapat merugikan keuangan negara atau perekonomian negara, dipidana dengan pidana penjara seumur hidup atau pidana penjara paling singkat 4 (empat) tahun dan paling lama 20 (dua puluh) tahun dan denda paling sedikit Rp. 200.000.000,(dua ratus juta rupiah) dan paling banyak Rp. 1.000.000.000,- (satu milyar rupiah)." Kemudian Pasal 3 Undang-Undang ini menyebutkan bahwa: "Setiap orang yang dengan tujuan menguntungkan diri sendiri atau orang lain atau suatu korporasi, menyalahgunakan kewenangan, kesempatan atau sarana yang ada padanya karena jabatan atau kedudukan yang dapat merugikan keuangan negara atau perekonomian negara, dipidana dengan pidana penjara

\footnotetext{
${ }^{12}$ Sudarsono, Kamus Hukum, Rineka Cipta, Jakarta, 2002

${ }^{13}$ Kartini Kartono dalam Septiana Dwiputrianti, Memahami Strategi Pemberantasan Korupsi Di Indonesia, Jurnal Administrasi STIA LAN Bandung, Vol. VI, No. 3, 2009, hal : 242 
seumur hidup, atau pidana penjara paling singkat 1 (satu) tahun dan paling lama 20 (dua puluh tahun) tahun dan atau denda paling sedikit Rp.50.000.000,- (lima puluh juta rupiah) dan paling banyak Rp.1.000.000.000,- (satu milyar rupiah).

Jika diidentifikasi maka suatu perbuatan dapat dikatakan tindak pidana korupsi apabila memenuhi unsur-unsur sebagai berikut: Pertama Suatu pengkhianatan terhadap kepercayaan; Kedua Penipuan terhadap badan pemerintah, lembaga swasta atau masyarakat pada umumnya; Ketiga Dengan sengaja melalaikan kepentingan umum untuk kepentingan khusus; Keempat Dilakukan dengan rahasia, kecuali dengan keadaan dimana orang-orang berkuasa atau bawahannya menganggapnya tidak perlu; Kelima Melibatkan lebih dari satu orang atau pihak; Keenam Adanya kewajiban dan keuntungan bersama dalam bentuk uang atau yang lain; Ketujuh Terpusatnya kegiatan korupsi pada mereka yang menghendaki keputusan yang pasti dan mereka yang dapat mempengaruhinya; Kedelapan Adanya usaha untuk menutupi perbuatan korupsi dalam bentuk pengesahan hukum; dan Kesembilan Menunjukkan fungsi ganda yang kontradiktif pada mereka yang melakukan korupsi. Selain dari identifikasi tersebut biasanya pelaku tindak pidana korupsi mulanya tidak mengakui perbuatannya, baik ditingkat penyelidikan, penyidikan dan pemeriksaan perkara di pengadilan, sehingga penanganannya perlu ekstra keseriusan dan kecermatan aparat penegak hukum, disamping itu ada kecenderungan untuk melakukan suap kepada aparat penegak hukum untuk mengaburkan perkaranya, paling tidak berupaya untuk meringankan hukumannya.

Tindak pidana korupsi sangat merugikan keuangan negara atau perekonomian negara dan menghambat pembangunan nasional, sehingga harus diberantas dalam rangka mewujudkan masyarakat adil dan makmur berdasarkan Pancasila dan UndangUndang Dasar 1945 serta mengembangkan kesadaran, sikap dan perilaku masyarakat anti korupsi agar tercipta dalam sistem hukum nasional. Terlebih daripada itu korupsi sudah merupakan persoalan yang mendasar, bukan saja persoalan lokal akan tetapi sudah menjadi fenomena nasional dan bahkan internasional, saat ini bangsa Indonesia telah ikut aktif dalam upaya masyarakat internasional untuk pencegahan dan pemberantasan tindak pidana korupsi dengan telah menandatangani United Nations Convention Against Corruption, 2003 (Konvensi Perserikatan BangsaBangsa Anti Korupsi, 2003) yang telah disahkan dengan Undang-Undang Republik Indonesia Nomor 7 Tahun 2006, tentang Pengesahan United Nations Convention Against Corruption, 2003 (Konvensi Perserikatan Bangsa-Bangsa Anti Korupsi 2003), dan salah satu pokokpokok isi konvensi adalah pencegahan dan penegakan hukum tindak pidana korupsi, termasuk penyuapan Pejabatpejabat publik, penggelapan, penyalahgunaan wewenang atau penyimpangan lain kekayaan oleh pejabat publik. 
Jika dilihat dari pengertian korupsi, maka yang paling besar berpeluang untuk melakukan tindak pidana korupsi adalah dikalangan pegawai negeri dalam bentuk penyalah gunaan wewenang, kesempatan, sarana jabatan atau kedudukannya, dan bahkah salah melakukan atau ketidak sengajaan. Pegawai negeri adalah pegawai yang bekerja di instansiinstansi pemerintah dan digaji oleh pemerintah. ${ }^{16}$ Kemudian berdasarkan Pasal 1 huruf (c) Undang-Undang Nomor 31 Tahun 1999, tentang Pemberantasan Tindak Pidana Korupsi, sebagaimana diubah dengan Undang-Undang Nomor 20 Tahun 2001, yang dimaksud pegawai negeri adalah : orang yang menerima gaji atau upah dari keuangan negara atau daerah; huruf (d). menyebutkan : orang yang menerima gaji atau upah dari suatu korporasi yang menerima bantuan dari keuangan negara atau daerah, dan huruf (e). menyebutkan : orang yang menerima gaji atau upah dari korporasi lain yang mempergunakan modal atau fasilitas dari negara atau masyarakat.

Pegawai negeri yang kerap disebut melakukan tindak pidana korupsi adalah mereka yang sedang melakukan tugas administrasi negara atau administrasi publik. Secara etimologi administrasi berasal dari bahasa latin (Yunani) yang terdiri atas dua kata, yaitu: "ad" dan "ministrate" yang berarti "to serve" yang dalam bahasa Indonesia berarti melayani dan atau memenuhi, ${ }^{17}$ sedangkan menurut kamus bahasa Indonesia administrasi adalah usaha dan kegiatan yang meliputi penetapan tujuan serta penetapan cara-cara penyelenggaraan pembinaan organisasi, kegiatan kantor dan tata usaha. ${ }^{18}$ Definisi administrasi, menurut Herbert A. Simon, adalah sebagai kegiatan kelompok kerja sama untuk mencapai tujuan-tujuan bersama. Menurut Dwight Waldo administrasi adalah suatu daya upaya yang kooperatif, yang mempunyai tingkat rasionalitas yang tinggi, menurut Demock mengatakan bahwa suatu ilmu yang mempelajari apa yang dikehendaki rakyat melalui pemerintah, dan cara mereka memperolehnya, menurut S.P. Siagian mendefinisikan administrasi sebagai keseluruhan proses kerja sama antar dua orang manusia atau lebih yang didasarkan atas rasionalitas tertentu mencapai tujuan yang telah ditentukan sebelumnya, The Liang Gie mendefinisikan administrasi adalah rangkaian kegiatan terhadap pekerjaan yang dilakukan oleh sekelompok orang didalam kerjasama mencapai tujuan tertentu. ${ }^{19}$ Kemudian jika diambil suatu kesimpulan maka definisi administrasi adalah pekerjaan terencana yang dilakukan oleh sekelompok orang dalam bekerja sama untuk mencapai tujuan atas dasar efektif, efisien, dan rasional. $^{20}$ Sedangkan menurut D.H. Kuntjoro istilah administrasi

\footnotetext{
${ }^{16}$ Ating Tedjasutiasna, Administrasi Kantor, Armico, Bandung, 1999, hal :22

${ }^{17}$ Harbani Pasolong, Teori Administrasi Publik, Alfabeta, Bandung, 2007, hal : 1

${ }^{18}$ Eko Hadi Wiyono, op cit, hal : 11

${ }^{19}$ Harbani Pasolong, op cit, hal : 2-3

${ }^{20}$ Ibid
} 
(administration) dapat diterjemahkan sebagai pemerintahan dan admistrare sebagai to manage yaitu mengelola atau melayani. Dalam konteks ini hukum administrasi negara dipahami sebagai himpunan peraturan yang mengatur hubungan antara administrasi negara dengan warga masyarakat, dimana administrasi negara diberi wewenang untuk melakukan tindakan hukum sebagai implementasi untuk policy dari suatu pemerintahan yang legitimited. ${ }^{21}$

Peluang yang paling besar untuk melakukan korupsi adalah pegawai negeri yang sedang melaksanakan tugas administrasi negara, maka administrasi yang dimaksud adalah administrasi negara atau administrasi publik $^{22}$ yaitu proses dimana sumber daya dan personil publik diorganisir dan dikoordinasikan untuk $\mathrm{m}$ e $\mathrm{m} \mathrm{for} \mathrm{m} \mathrm{l}$ a s i $\mathrm{kan}$, mengimplementasikan, dan mengelola (manage) keputusan dalam kebijakan publik, semua kebijakan tersebut merupakan tindakan pemerintah, yaitu suatu tindakan yang dilakukan oleh suatu badan atau Pejabat Tata Usaha Negara dalam rangka melaksanakan urusan pemerintahan, yang terdiri dari beberapa unsur, yaitu pertama Perbuatan itu dilakukan oleh aparat pemerintah dalam kedudukannya sebagai penguasa maupun sebagai alat perlengkapan pemerintahan (bestuursorganen) dengan prakarsa dan tanggung jawab sendiri; kedua Perbuatan tersebut dilaksanakan dalam rangka menjalankan fungsi pemerintahan; ketiga Perbuatan tersebut dimaksudkan sebagai sarana untuk menimbulkan akibat hukum dibidang hukum administrasi negara; keempat Perbuatan yang bersangkutan dilakukan dalam rangka memelihara kepentingan negara dan rakyat. ${ }^{23}$

Dalam negara hukum segala tindakan pemerintah yang dilakukan harus berdasar atas hukum secara legalitas, baik di pemerintah pusat maupun pemerintah daerah, biasanya dasar hukum yang ditetapkan dalam rangka menjalankan tugas pemerintahan disebut Keputusan Tata Usaha Negara, berdasarkan Pasal 1 ayat (3) Undang-Undang Nomor 5 Tahun 1986, tentang Peradilan Tata Usaha Negara, menyebutkan bahwa yang dimaksud Keputusan Tata Usaha Negara (KTUN) adalah: "suatu penetapan tertulis yang dikeluarkan oleh badan atau Pejabat Tata Usaha Negara yang berisi tindakan hukum Tata Usaha Negara berdasarkan peraturan perundang-undangan yang berlaku, yang bersifat final, yang menimbulkan akibat hukum bagi seseorang atau badan hukum perdata." Jika disimpulkan terdapat elemenelemen utama sebagai berikut : (a) Penetapan tertulis; (b). (oleh) badan atau pejabat Tata Usaha Negara, (c). Tindakan hukum Tata Usaha Negara; (d). Konkrit, individual; (e). Final; (f). Akibat hukum bagi seseorang atau badan hukum perdata.

\footnotetext{
${ }^{21}$ D.H. Kuntjoro, Hukum Adiministrasi Negara, Galia Indonesia, Jakarta, 2004, hal : 4

${ }^{22}$ Yaremis T Keban, Op Cit, hal : 3

${ }^{23}$ Titik Triwulan Tutik, Pengantar Hukum Tata Usaha Negara Indonesia, Prestasi Pustaka, Jakarta, 2010, hal : 190-191
} 
Pengertian penetepan tertulis pada huruf (a) maksudnya adalah cukup ada hitam di atas putih, karena menurut penjelasan atas pasal tersebut dikatakan bahwa "form" tidak penting dan bahkan nota atau memo saja sudah memenuhi syarat sebagai penetapan tertulis, sedangkan pengertian badan atau pejabat tata usaha negara dirumuskan dalam Pasal 1 angka 2 Undang-Undang Nomor 5 Tahun 1986, tentang Peradilan Tata Usaha Negara, pada dasarnya badan atau pejabat tata usaha negara melakukan urusan pemerintahan, kemudian pada penjelasan Pasan 1 angka 1 menyatakan yang dimaksud dengan pemerintahan adalah kegiatan yang bersifat ekskutif; menurut Philipus M. Hadjon yang dimaksud ekskutif atau pemerintahan pada dasarnya tidak hanya melaksanakan Undang-Undang tetapi atas dasar "freies ermessen" dapat melakukan perbuatan-perbuatan lainnya meskipun belum diatur secara tegas oleh Undang-Undang. ${ }^{24}$ Sedangkan unsur-unsur "freies ermessen" dalam suatu negara hukum adalah sebagai berikut: (1). Ditujukan untuk menjalankan tugas-tugas servis publik; (2). Merupakan sikap tindak yang aktif dari adminstrai negara; (3). Sikap tindak itu dimungkinkan oleh hukum; (4). Sikap tindak itu diambil atas inisiatif sendiri; (5). Sikap tindak itu dimaksudkan untuk menyelesaikan persoalan-persoalan penting yang timbul secara tiba-tiba; dan (6). Sikap tindak itu dapat dipertanggung jawabkan baik secara moral kepada Tuhan Yang Maha Esa maupun secara hukum. ${ }^{25}$

${ }^{24}$ Philipus M. Hadjon, dalam Ibid, hal : 250

${ }^{25} \mathrm{Ibid}$, hal : 218
Pada dasarnya perbuatan pemerintah (administrasi) dapat dikategorikan menjadi 3 (tiga) macam, yaitu : (1). Mengeluarkan peraturan perundang-undangan (regelling); (2). Mengeluarkan keputusan (beschikking); dan (3). Melakukan perbuatan material (meterielle daad). Perbuatan hukum yang dilakukan oleh aparat administrasi negara berdasarkan wewenang istimewa dalam hal membuat suatu ketetapan/keputusan bertujuan untuk mengatur hubungan antara sesama administrasi negara maupun antara administrasi negara dan warga masyarakat, sedangkan yang dimaksud pemerintahan adalah dari pemerintah pusat sampai pada pemerintah daerah. Pada pemerintah pusat dilaksanakan oleh Persidan dan Wakil Presiden bersama dengan Menteri-Menterinya, sedangan pemerintah daerah dilaksanak oleh kepala daerah yaitu Gubernur dan Wakil Gubernur, Bupati dan Wakil Bupati serta Walikota dan wakil walikota. Apabila dikaitkan dengan persoalan dalam permasalahan diatas, yaitu mengenai pembebasan tanah di desa Pulau Atas kecamatan Samarinda ilir kota Samarinda, yang menjadi dasar pertama selain Undang-Undang adalah Peraturan Presiden Republik Indonesia Nomor 36 Tahun 2005, tentang Pengadaan Tanah Bagi Pelaksanaan Pembanguan Untuk Kepentingan Umum, kemudian diperbaharui dengan Peraturan Presiden Republik Indonesia Nomor 65 Tahun 2006, tentang Perubahan Atas Peraturan Presiden Nomor 35 Tahun 2005, tentang Pengadaan Tanah Bagi Pelaksanaan 
Pembangunan Untuk Kepentingan Umum.

Bahwa Peraturan Presiden Nomor 65 Tahun 2006 merupakan (regelling), yaitu suatu peraturan mengenai tata cara pengadaan tanah untuk kepentingan umum, kemudian ditindak lanjuti oleh Keputusan Wali Kota Samarinda Nomor: 59005/170/HK-KS/2007, tentang Pembentukan Panitia Pengadaan Tanah Bagi Pelaksanaan Pembangunan Untuk Kepentingan Umum Di Wilayah Kota Samarinda, Keputusan Wali Kota tersebut bersifat ketetapan atau putusan (beschikking), mengikat kepada pejabat administrasi negara sesuai dengan jabatannya mesing-masing, yang disebutkan didalamnya yaitu Asisten Pemerintahan dan Hukum Setkot Samarinda sebagai ketua, Kepala Bagian Perkotaan Setkot Samarinda sebagai sekertaris, Kepala Dinas Pemukiman dan Pengembangan Kota Sekot Samarinda sebagai anggota, Kepala Dinas Pertanian, Perkebunan, dan Kehutanan Kota Samarinda sebagai anggota, Kepala Kantor Pertanahan Kota Samarinda sebagai anggota, Kepala Kantor Pelayanan Pajak Bumi dan Bangunan Kota Samarinda sebagai anggota, Kepala bagian Perlengkapan Setkot Samarinda sebagai anggota, Kasi Hak Tanah dan Pendaftaran Tanah pada kantor Pertanahan Kota Samarinda sebagai anggota, Camat terkait sebagai anggota, Lurah terkait sebagai anggota dan Instansi terkait sebagai anggota,untuk menjalankan tugas administrasi sesuai dengan peraturan perundang-undangan yang berlaku

${ }^{26}$ Tribu Kaltim, Jumat, 3 Desember 2010, hal : 1 serta bertanggung jawab kepada Walikota Samarinda.

\section{Analisis Dan Pembahasan}

Tindak pidana korupsi yang paling sering terjadi adalah di kalangan birokrasi atau pejabat administrasi di daerah yang sedang malaksanakan tugas administrasi negara, baik itu menjalankan tugas berupa peraturan daerah (regelling) maupun menjalankan tugas surat keputusan kepala daerah yang bersifat penetapan (beschikking). Tindak pidana korupsi merupakan target operasi di Indonesia, sehingga para aparat penegak hukum selalu mengawasi pelaksanaan peraturan-peraturan apakah ada penyimpangan dalam prakteknya, bukan saja yang secara langsung dengan sengaja merugian keuangan negara atau perekonomian negara, tetapi lebih luas dari itu dikategarikan sebagai tindak pidana korupsi. Salah dalam manjalankan peraturan dan tidak konsisten dalam menaksir harga tanah dalam hal pembebasan tanah milik masyarakat kepada pemerintah, sehingga harga taksiran dianggap lebih tinggi yang menimbulkan kerugian negara termasuk melanggar UndangUndang Tindak Pidana korupsi. Hal itu terjadi kasus di Samarinda mengenai pembebasan tanah untuk kepentingan pembangunan gardu PLN; ${ }^{26}$ Pejabat administrasi negara yang sedang menjalankan tugas administrasi dilakukan oleh pejabat Satuan Kerja Perangkat Daerah (SKPD) adalah kepala-kepala dinas pada pemerintahan kota Samarinda yang menjalankan SK Walikota Samarinda dapat terjerat kasus korupsi. 


\section{Kasus Posisi}

Berdasarkan Surat Keputusan (SK) Walikota Samarinda Nomor 590-05/170/HK-KS/2007, tanggal 23 Maret 2007 tentang Pembentukan Panitia Pengadaan Tanah bagi Pelaksanaan Pembangunan untuk Kepentingan Umum di Wilayah Kota Samarinda, dengan susunan personalia sebagai berikut:

- Penanggung jawab : Walikota Samarinda

- Wakil Penanggungjawab :

1. Wakil Walikota Samarinda

2. Sekretaris Daerah Kota Samarinda

- Ketua : Asisten Pemerintahan dan Hukum Setkot Samarinda.

- Sekeretaris : Kepala Bagian Perkotaan Setkot Samarinda.

- Anggota:

1. Kepala Dinas Pemukiman dan P engembangan Kota Samarinda;

2. Kepala Dinas Pertanian, Perkebunan, dan Kehutanan Kota Samarinda;

3. Kepala Kantor Pertanahan Kota Samarinda;

4. Kepala kantor Pelayanan Pajak Bumi dan Bangunan Kota Samarinda;

5. Kepala Bagian Perlengkapan Setkot Samarinda;

6. Camat Terkait;

7. Lurah terkait dan

8. Instansi terkait.

Bahwa sesuai SK Walikota tentang Pembentukan Panitia Pengadaan Tanah tersebut panitia mempunyai tugas sebagai berikut:

1. Mengadakan penelitian dan inventarisasi atas tanah, bangunan, tanaman dan bendabenda lain yang ada kaitannya dengan tanah yang haknya akan dilepaskan atau diserahkan;

2. Mengadakan penelitian mengenai status hukum tanah yang haknya akan dilepaskan atau diserahkan dan dokumen yang didukung;

3. Menaksir dan mengusulkan besarnya ganti kerugian/ santunan atas tanah, bangunan, tanaman dan benda-benda lain yang ada kaitannya dengan tanah yang haknya akan dilepaskan atau diserahkan;

4. Memberikan penjelasan atau penyuluhan kepada pemilik/pemegang hak atas tanah mengenai rencana dan tujuan pengadaan tanah tersebut;

5. Mengadakan musyawarah dengan para pemilik/ pemegang hak atas tanah dan instansi pemerintah yang memerlukan tanah dalam rangka menetapkan bentuk dan atau besarnya ganti kerugian/ santunan;

6. Menyaksikan pelaksanaan penyerahan uang ganti kerugian/santunan kepada para pemilik/pemegang hak atas tanah, bangunan, tanaman, dan benda-benda lain yang ada diatas tanah tersebut; dan 
7. Membuat Berita Acara Pelepasan $\mathrm{Hak}$ atas Penyerahan Hak Atas Tanah.

Bahwa Atas dasar SK Walikota tersebut, ketua dan para anggota yang menjalankan tugas administrasi negara membebaskan lahan milik salah seorang warga masyarakat seluas 3,7 Ha, yang terletak di desa Pulau Atas Samarinda Ilir kota Samarinda, untuk kepentingan mendirikan Gardu Induk PLN. Atas kerja panitia tersebut kemudian Kejaksaan Tinggi Kaltim menyelidiki, memeriksa adanya indikasi tindak pidana korupsi. Ketua dan para anggota panitia ditetapkan sebagai tersangka dan terdakwa kemudian dituntut (berkas perkara dipisah) sebagaimana diatur dan diancam pidana dalam Pasal 3 jo. Pasal 18 Undang-Undang Rapublik Indonesia Nomor 31 Tahun 1999 tentang Pemberantasan Tindak Pidana Korupsi sebagaimana diubah dan ditambah dengan Undang-Undang Republik Indonesia Nomor 20 Tahun 2001 tentang Perubahan atas UndangUndang Republik Indonesia Nomor 31 Tahun 1999 tentang Perubahan atas Tindak Pidana Korupsi Jo. Pasal 55 Ayat (1) ke-1 KUHP, agar Pengadilan Negari Samarinda menjatuhkan pidana masingmasing 5 (lima) tahun penjara dengan dikurangi selama terdakwa ditahan dan pidana denda sebesar Rp. 500.000.000,- (lima ratus juta rupiah), subsidair 3 (tiga) bulan kurungan.

B a hwa berdasarkan pertimbangan Majelis Hakim yang pada intinya berkesimpulan bahwa terdakwa kurang cermat dalam menaksir harga tanah sesuai SK Walikota Nomor : 590-05/170/HKKS/2007 angka 3 (tiga), sehingga penjual/pemilik tanah memperoleh keuntungan yang tidak wajar. Majelis Hakim menjatuhkan hukuman pidana kepada ketua panitia (Asisten Pemerintahan dan Hukum Setkot Samarinda), karena telah terbukti secara sah dan meyakinkan bersalah melakukan tindak pidana korupsi yang dilakukan secara bersama-sama, dengan pidana penjara selama 1 (satu) tahun 6 (enam) bulan, dan membayar denda sebesar Rp. 50.000.000,- (lima puluh juta rupiah), dengan ketentuan apabila denda tersebut tidak dibayar diganti dengan pidana kurungan selama 3 (tiga) bulan. ${ }^{27}$ Hukuman yang sama juga dijatuhkan kepada lurah Pulau Atas, kemudian panitia yang lain dijatuhi hukuman masing-masing 1 (satu) tahun, kecuali Kepala Kantor Pelayanan Pajak Bumi dan Bangunan Kota Samarinda dan pemilik tanah di fonis bebas. ${ }^{28}$

2. Pegawai Negeri Yang Sedang Menjalankan Tugas Administrasi Negara Dapat Dijatuhi Pidana Korupsi.

Berdasarkan pemahaman yang

${ }^{27}$ Putusan Pengadilan Negeri Samarinda, Nomor: 620/Pid.B/2010/PN Smda, tanggal 23 Nopember 2010.

${ }^{28}$ Tribun Kaltim: Selasa, 30 Nopember 2010, hal: 1. Rabu, 1 Desember 2010, hal: 1. Jumat, 3 Desember 2010, hal: 1. Sabtu, 4 Desember 2010, hal: 1 
terkandung dalam Pasal 2 ayat (1) Undang-Undang Nomor 31 Tahun 1999, tentang Pemberantasan Tindak Pidana Korupsi, sebagaimana diubah dan ditambah dengan Undang-Undang Nomor 20 Tahun 2001 yang dimaksud korupsi adalah perbuatan setiap orang secara melawan hukum dengan maksud memperkaya diri sendiri/orang lain (perseorangan atau korporasi) yang dapat merugikan k e uangan/ perekonomian negara. Dengan demikian unsur-unsurnya adalah (1). Setiap orang; (2). Secara melawan hukum; (3). Memperkaya diri sendiri atau orang lain; (4). Dapat merugikan keuangan/ perekonomian negara. Kemudian pemahaman Pasal 3 UndangUndang tersebut yang dimaksud korupsi adalah perbuatan setiap or a n g dengan tujuan menguntungkan diri sendiri/orang lain (perseorangan/korporasi) menyalahgunakan wewenang yang dapat merugikan keuangan/ perekonomian negara, sehingga unsur-unsurnya adalah (1). Setiap orang; (2). Dengan tujuan menguntungkan diri sendiri atau orang lain; (3). Menyalahgunakan wewenang; (4). Dapat merugian keuangan/perekonomian negara.

Unsur setiap orang bisa disamakan dengan barang siapa yang biasa dipergunakan dalam KUHP. Menurut putusan Mahkamah Agung Republik I $\mathrm{n} \mathrm{d}$ o $\mathrm{n}$ e s i a $\mathrm{N}$ o m o r : 1398.K/Pid/1994 yang dimaksud dengan "setiap orang" adalah sama dengan terminologi kata "barang siapa" adalah setiap orang atau pribadi yang merupakan subyek hukum yang melakukan suatu perbuatan pidana atau subyek pelaku dari pada suatu perbuatan pidana yang dapat dimintai pertanggung jawaban atas segala tindakannya. Sedangkan yang dimaksud pegawai negeri seperti yang termuat dalam Pasal 1 ayat (2) Undang-Undang Nomor 31 Tahun 1999, tentang Pemberantasan Tindak Pidana Korupsi sebagaimana diubah dalam Undang-Undang Nomor 20 Tahun 2001, yaitu meliputi (a). Pegawai negeri sebagaimana UndangUndang tentang Kepegawaian; (b). Pegawai negeri sebagaimana dimaksud dalam KUHP; (c). Orang yang menerima gaji atau upah dari lingkungan negara atau daerah; (d). Orang yang menerima gaji atau upah dari suatu korporasi yang menerima bantuan dari keuangan negara atau daerah; atau (e). Orang yang menerima gaji atau upah dari k orporas i la in y a n mempergunakan modal atau fasilitas dari negara atau masyarakat. Secara normati pegawai negeri merupakan orang atau pribadi yang merupakan subyek hukum dan dapat dimintai pertanggung jawaban atas segala tindakannya termasuk perbuatan pidana korupsi.

Apabila ditelaah lebih lanjut pegawai negeri yang dapat terkena sanksi pidana korupsi adalah pegawai negeri yang melakukan kesalahan seperti diatur dalam UU tindak pidana korupsi, dalam menjalankan tugas administrasi 
negara atau sedang menjalankan pelayanan publik, berdasarkan Pasal 1 ayat (1) Undang-Undang Nomor 25 Tahun 2009, tentang Pelayanan Publik. Pelayanan publik adalah kegiatan atau rangkaian kegiatan dalam rangka pemenuhan kebutuhan pelayanan sesuai dengan peraturan perundangan bagi setiap warga negara dan penduduk atas barang, jasa. Atau pelayanan administratif yang disediakan oleh penyelenggara pelayanan publik. Dalam konteks ini penyelenggara pelayanan publik (penyelenggara) adalah setiap institusi penyelenggara negara, korporasi, lembaga independen yang dibentuk berdasar Undang-Undang untuk kegiatan pelayanan publik dan badan hukum lain yang dibentuk semata-mata untuk kegiatan pelayanan publik.

Adapun maksud dan tujuan dari pelayanan publik itu adalah dalam rangka memberikan kepastian hukum dalam hubungan antara masyarakat dengan penyelenggara dalam pelayanan publik, mengatur hubungan yang jelas antara hak dan tanggung jawab, kewajiaban dan kewenangan seluruh pihak yang terkait dengan penyelenggaraan pelayanan publik, selain itu juga bertujuan untuk mewujudkan sistem penyelenggaraan pelayanan publik yang layak sesuai dengan asas-asas umum pemerintahan dan korporasi yang baik serta terpenuhinya penyelenggaraan pelayanan publik sesuai dengan peraturan perundangan dan kepastian hukum bagi masyarakat dalam penyelenggaraan pelayanan publik yang diberikan oleh administrasi negara. ${ }^{29}$

Pegawai negeri dapat dikategorikan unsur setiap orang yang termuat dalam UndangUndang Nomor 31 Tahun 1999, tentang Pemberantasan Tindak Pidana Korupsi sebagaimana diubah dalam Undang-Undang Nomor 20 Tahun 2001, sehingga setiap pegawai negeri yang sedang melakukan tugas administrasi dapat dijatuhi hukuman pidana korupsi apabila dalam melakukan tugasnya terdapat unsur melawan hukum, memperkaya diri sendiri/orang lain atau suatu korporasi, dan dapat m e r u gikan ke uangan/ perekonomian negara. Apabila pegawai negeri yang sedang melaksanakan tugasnya tersebut terdapat unsur ing in menguntungkan diri sendiri atau orang lain atau suatu korporasi, dengan menyalah gunakan wewenang yang dimilki atau kesempatan sarana yang ada padanya karena jabatan atau kedudukannya sehingga dapat merugikan keuangan/ perekonomian negara, juga termasuk kategosi korupsi. Jika dikaji lebih dalam pemahaman tentang tindak pidana korupsi itu bukan saja mereka para koruptor itu secara langsung ada keinginan untuk memperkaya diri sendiri, tetapi lebih dari itu seperti menyalah gunakan wewenang dan termasuk

${ }^{29}$ Nomensen Sinamo, Hukum Administrasi Negara, Jala Pratama Aksara, Jakarta, 2010, hal : 62 
salah dalam melaksanakan tugas administrasi negara dapat terancam pidana korupsi apabila ada unsur merugian keuangan/perekonomian negara.

Unsur kedua tentang Perbuatan melawan hukum yang dimaksud dalam Undang-Undang Nomor 31 Tahun 1999, tentang Tindak Pudana Korupsi sebagaimana diubah dengan Undang-Undang Nomor 20 Tahun 2001, mencangkup perbuatan melawan hukum dalam arti formil maupun dalam arti materiil, yakni meskipun perbuatan tersebut tidak diatur dalam peraturan perundang-undangan, namun apabila perbuatan tersebut dianggap tercela karena tidak sesuai dengan rasa keadilan atau normanorma kehidupan sosial dalam masyarakat, maka perbuatan tersebut dapat dipidana. Dalam ketentuan pasal tersebut kata "dapat" sebelum frasa "merugikan keuangan atau perekonomian negara" menunjukkan bahwa tindak pidana korupsi merupkan delik formil. Delik formil adalah adanya tindak pidana korupsi cukup dengan dipenuhinya unsur-unsur perbuatan yang sudah dirumuskan bukan timbulnya akibat, walaupun tindak pidana korupsi tersebut akan berakibat banyak merugikan keuangan negara, menghambat pembangunan disegala bidang, karena perbuatan korupsi yang diambil adalah uang Negara. Uang negara merupakan kekayaan rakyat yang seharusnya dapat d i p e r g u n a k a n $\mathrm{n} \mathrm{tuk}$ mensejahterakan rakyat. Perbuatan korupsi bisa berakibat krisis ekonomi yang menimbulkan $\mathrm{k}$ e m is kinan terma suk meningkatnya angka kriminalitas dan membahayakan bagi kehidupan bangsa, oleh karena itu dalam hal keadaan tertentu pelaku tindak pidana korupsi dapat dijatuhi hukuman mati.

Salah satu penyebab korupsi adalah faktor penegakan hukum yang tidak konsisten, selama ini penegakan hukum kasus korupsi masih terpengaruh dengan masalah politik, sehingga pemberantasan korupsi masih terkesan tebang pilih dan belum merata. Penjatuhan pidana korupsi kurang maksimal, walaupun secara normatif tindak pidana korupsi dapat dijatuhi hukuman mati tetapi selama ini di Indonesia belum pernah terjadi, bahkan ketua Mahkamah Konstitusi Mahfud MD setuju koruptor dihukum mati, alasannya adalah bahwa hukuman kurungan penjara atau denda tidak mampu memberikan efek jera kepada para koruptor, tetapi yang terpenting adalah bagaimana menciptakan suasana dan kesadaran anti korupsi yang harus ditanamkan sejak dini sehingga terbetuklah karakter anti korupsi. $^{30}$

Perbuatan korupsi yang lebih semarak adalah dalam bentuk penyuapan atau pemberian suap yang dilakukan oleh para pengusaha dan kaum profesional, bahkan tidak sedikit dikalangan penegak hukum

${ }^{30}$ Mahfud MD, Kaltim Pos, Minggu, 17 Oktober 2010, hal : 1 
seperti Polisi, Jaksa Advokat dan juga kepada Hakim, seperti yang dilansir dalam Kaltim Pos : "Gayus beberkan aliran dana ke Jaksa, total 25 Milyar lewat Pengacara selama proses penyidikan." ${ }^{31}$ Diungkapkan pula oleh Fajroel Falaakh anggota Komisi Hukum Nasional (KHN) bahwa tujuh puluh persen penegak hukum seperti Kejaksaan, Kepolisian, dan Kehakiman, dinilai terindikasi melakukan tindak pidana korupsi. Padahal Jaksa, Polisi dan Hakim yang sedang menjalankan tugasnya adalah pegawai negeri yang menjalankan tugas adminstrasi negara, Hal itu pula yang menyebabkan selama 10 tahun terakhir ini penegakan hukum di Indonesia tidak menunjukkan perkembangan yang berarti. ${ }^{32}$

Harus diakui bahwa peluang pegawai negeri untuk melakukan korupsi begitu besar, baik itu perbuatan yang disengaja atau tidak sengaja dengan melawan hukum, atau dalam bentuk menyalah gunakan kewenangan, kesempatan, sarana jabatan, atau kedudukannya termasuk penerima dan pemberi suap kepada para pegawai negeri yang sedang bertugas, atau berkaitan dengan kedudukannya sebagai pegawai negeri yang sedang menjalankan tugas administrasi. Bentuk korupsi seperti tersebut diatas dapat saja dilakukan dikantor pemerintah pusat, pemerintah daerah dan pada aparat penegak hukum seperti Polisi, Jaksa dan
Hakim. Dari semua itu dapat dikategorikan korupsi asalkan sudah terpenuhi unsur-unsurnya, apalagi unsur merugikan keuangan atau perekonomian negara telah terpenuhi, oleh karena itu bagi semua pegawai negeri harus berhati-hati dalam menjalankan tugasnya, disamping itu harus selalu menciptakan suasa dan perilaku anti korupsi.

\section{Dampak Penjatuhan Pidana} Korupsi Bagi Pegawai Negeri Yang Sedang Melaksanakan Tugas Administrasi Negara.

Perbuatan korupsi adalah jika seorang pengabdi negara (pegawai $\mathrm{n}$ e ge r i ) m e n g a $\mathrm{g} g$ a $\mathrm{p}$ kantor/instansinya sebagai perusahaan dagang, sehingga dalam pekerjaannya akan diusahakan memperoleh pendapatan sebanyak mungkin, sedangkan titik berat jabatan pemerintah dikatakan korupsi apabila pejabat menerima uang sebagai dorongan untuk melakukan sesuatu yang sebenarnya bisa dilakukan dalam tugas dan jabatannya, padahal ia tidak diperbolehkan melakukan hal seperti itu selama menjalankan tugasnya. ${ }^{33}$ Mengenai rumusan korupsi menurut pendapat Syeh Hussein Alatas bahwa terjadinya korupsi adalah apabila seorang pegawai negeri menerima pemberian yang disodorkan oleh seorang dengan maksud mempengaruhinya a gar memberikan perhatian istimewa

${ }^{31}$ Tribun Kaltim, Sabtu, 16 Oktober 2010, hal : 1

${ }^{32}$ Fajroel Falaakh, Suara Karya, Kamis 30 Desember 2010, hal : 1

${ }^{33}$ IGM Nurdjana, Korupsi Dalam Praktek Bisnis, Gramedia Pustaka Utama, Jakarta, 2003, hal : 8 
pada kepentingan-kepentingan si pemberi. Kadang-kadang juga berupa perbuatan menawarkan pemberian uang hadiah lain yang dapat menggoda pejabat. Termasuk dalam pengertian ini juga pemerasan, yakni permintaan pemberian atau hadiah seperti ini dalam pelaksanaan tugas-tugas publik yang mereka urus bagi keuntungan mereka sendiri., ${ }^{34}$

Beberapa faktor yang menyebabkan terjadinya korupsi m e nurut R. D jat miko Soemodihardjo adalah:

- Greeds (keserakahan) yang berkaitan dengan adanya perilaku serakah yang secara potensial ada didalam diri setiap orang;

- Opportunies (kesempatan) yang berkaitan dengan keadaan organisasi, instansi atau masyarakat, sehingga terbuka kesempatan bagi seseorang untuk melakukan korupsi;

- Needs (kebutuhan) yang berkaitan dengan faktor kebutuhan individu guna menunjang hidupnya yang layak; dan

- Exposures (pengungkapan) yaitu faktor yang berkaitan dengan tindakan, konskwensi atau resiko yang akan dihadapi oleh pelaku apabila yang bersangkutan terungkap melakukan korupsi. ${ }^{35}$

Dampak korupsi secara umum adalah merugikan keuangan negara dan merusak sendi-sendi kebersamaan serta memperlambat tercapainya tujuan nasional, diantaranya adalah Pertama tata ekonomi seperti pemborosan sumber-sumber, larinya modal ke luar negeri, gangguan terhadap perusahaan, gangguan penanaman modal, mundurnya sponsor maupun pendukung dana dan mitra; Kedua, tata sosial budaya seperti revolusi sosial dan ketimpangan sosial; Ketiga tata politik seperti ketidak stabilan politik, pengambil alihan kekuasaan, hilangnya bantuan luar negeri, hilangnya kewibawaan pemerintah; Keempat, tata administrasi seperti tidak efisien, kurangnya kemampuan administrasi, hilangnya keahlian, hilangnya sumber-sumber negara, keterbatasan kebijaksanaan pemerintah, dan pengambilan tindakan-tindakan represif. ${ }^{36}$

Lebih lanjut Mc Mullan menyatakan bahwa akibat korupsi adalah ketidak efisienan, ketidak adilan, rakyat tidak mempercayai pemerintah, memboroskan sumbersumber negara, tidak mendorong perusahaan untuk berusaha terutama perusahaan asing, ketidak stabilan politik, pembatasan dalam kebijaksanaan pemerintah dan lemahnya penegakan hukum. ${ }^{37}$ Dengan demikian korupsi akan

${ }^{34}$ Syeh Hussein Alatas dalam Ibid, hal : 10

${ }^{35}$ R. Djatmiko Soemodihardjo, Mencegah dan Memberantas Korupsi, Mencermati Dinamikanya di Indonesia, Prestasi Pustka Plubliser, Jakarta, 2008, hal : 153-154

${ }^{36}$ Mc. Mullan dalam Septiana Dwiputriani, op cit, hal : 248

${ }^{37} \mathrm{Ibid}$. 
berdampak lebih luas lagi yaitu terhambatnya pembangunan nasional, menghambat perkembangan kegiatan usaha di Indonesia sehingga menimbulkan ekonomi biaya tinggi, rakyat semakin menderita kemudian angka kemiskinan semakin tinggi, serta angka pengangguran semakin besar yang berakibat pula pada meningkatnya angka kriminalitas.

Bagi pegawai negeri yang dijatuhi hukuman karena tuduhan telah melakukan tindak pidana korupsi akan berdampak yang bersangkutan diberhentikan dengan tidak hormat. Berdasarkan UndangUndang Nomor 43 Tahun 1999 perubahan atas Undang-Undang Nomor 8 Tahun 1974, tentang pokok-pokok kepegawaian dijelaskan bahwa pegawai negeri dapat diberhentikan dengan tidak hormat karena : (1). Dihukum penjara berdasarkan keputusan pengadilan yang telah mempunyai kekuatan hukum tetap karena melakukan tindak pidana kejahatan yang diancam hukumannya 4 (empat) tahun lebih, dan (2). Melakukan pelanggaran disiplin pegawai negeri sipil tingkat berat. Apabila dikaitkan dengan ancaman hukuman yang termuat dalam Undang-Undang Nomor 31 Tahun 1999, tentang Pemberantasan Tindak Pidana Korupsi sebagaimana diubah dengan Undang-Undang Nomor 20 Tahun 2001, seperti yang termuat dalam Pasal 2 ayat (1) dan Pasal 3, ancaman hukumannya paling tinggi adalah seumur hidup dan denda paling tinggi Rp.1.000.000.000,(satu milyar rupiah). Dilihat dari kedua ketentuan tersebut maka ancaman pemberhentian dengan tidak hormat bagi tindak pidana korupsi bagi pegawai negeri sudah memenuhi syarat, sehingga dapat dikatakan bahwa hukuman bagi pelaku tindak pidana korupsi sangat tinggi dan menakutkan, ini merupakan bentuk keseriusan negara dalam pemberantasan tindak pidana korupsi di Indonesia.

Penjatuhan pidana korupsi juga berdampak kepada pegawai negeri lainnya, yaitu dampak positif dan negatif. Dampak positif adalah para pegawai negeri dilingkungan Pemkot Samarinda akan sangat hati-hati dalam menjalankan tugasnya dan biasanya tidak mau sembarangan begitu saja dapat diperintah oleh atasannya untuk melakukan suatu pekerjaan apalagi yang kiranya membahayakan, disertai pula memperhatikan peraturan yang ada jangan sampai ada peraturan yang dilanggarnya karena dampaknya akan terkena sangksi pidana sehingga akan memperkecil upaya untuk melakukan korupsi. ${ }^{38}$ Mengenai dampak negatifnya adalah para pegawai negeri yang menerima tugas administrasi ketakutan untuk menjalankan tugasnya, dan bahkan ada sebagian yang ada keinginan untuk menolak tugas yang diberikan kepadanya dengan alasan takut tersangkut kasus korupsi walaupun

${ }^{38}$ Kesimpulan hasil wawancara dengan beberapa pegawai negeri dilingkungan Pemkot Samarinda. 
sebenarnya dalam benaknya tidak ada niat untuk melakukan korupsi. ${ }^{39}$

Dari hasil penelitian yang didapat, berdasarkan wawancara dengan beberapa pegawai negeri di Pemkot Samarinda, sebenarnya ada pengakuan betapa ancaman mengenai hukuman karena melakukan korupsi sangat ditakuti oleh kalangan pegawai negeri di Pemkot Samarinda. Harapannya dalam menjalankan tugas administrasi negara diperlukan pendampingan dibidang hukum, karena sebenarnya unsur kesengajaan untuk melakukan korupsi itu tidak ada, hanya ketidak tauan dan kurang ketelitian dalam menjalankan tugasnya, sehingga menyebabkan suatu yang fatal kemudian harus menerima hukuman karena dianggap melakukan tindak pidana korupsi. Disisi lain memang mental sebagian pegawai negeri berkeinginan untuk mendapatkan penghasilan yang lebih banyak dari gaji yang sudah diterimanya.

Kasus yang menimpa para pegawai negeri Pemkot Samarinda dalam menjalankan tugas administrasi yaitu pembebasan tanah untuk pembanguan gardu PLN sudan diputus oleh majelis hakim Pengadilan Negeri Samarinda, apapun yang sudah menjadi putusan pengadilan harus dianggap benar, karena Hakim dalam menjalankan fungsi judisialnya menggunakan prinsip keagamaan dan prinsi Ketuhanan, misalnya dalam tiap putusannya selalu diawali dengan kata-kata "Demi Keadilan Berdasarkan Ketuhanan Yang Maha Esa", pernyataan ini memiliki implikasi yang sangat besar dalam memutus suatu perkara, pertanggung jawabannya tidak hanya kepada manusia tetapi juga kepada Tuhan. ${ }^{40}$ Putusan pengadilan (Yurisprudensi) merupakan sumber hukum formal di Indonesia, sedangkan putusan pengadilan tersebut hanya dapat dianulir atau dibatalkan oleh tingkat peradilan yang lebih tinggi, yaitu Pengadilan Tinggi dan/atau Mahkamah Agung Republik Indonesia.

\section{E. KESIMPULAN}

Berdasarkan hasil analisis dan pembahasan di atas maka bisa diambil beberapa kesimpulan sebagai berikut:

1. Pegawai negeri dapat dijatuhi pidana korupsi karena pegawai negeri secara normatif juga merupakan subyek hukum yang dapat dipertanggung jawabkan apabila melakukan tindak pidana termasuk tindak pidana korupsi. Pegawai negeri yang dapat dijatuhi hukuman korupsi adalah mereka yang sedang menjalankan tugas administrasi negara dengan secara melawan hukum memperkaya atau 
menguntungkan diri sendiri atau orang lain baik segaja atau tidak $\mathrm{s}$ e $\mathrm{n} \mathrm{g}$ a j a $\mathrm{t}$ e r m a s u k menyalahgunakan kewenangan, kesempatan atau sarana yang ada padanya karena jabatan dan kedudukan, termasuk suap, yang dapat merugikan keuangan/ perekonomian negara. Peluang untuk melakukan tindak pidana korupsi bagi pegawai negeri sangat besar, oleh karena itu bagi pegawai negeri harus berhati-hati dalam menjalankan tugas administrasi negara disamping itu harus menciptakan suasana anti korupsi.

2. Korupsi akan berdampak merusak perekonomian dan pembangunan nasional, yang menimbulkan kemiskinan, menambah tingginya angka pe ng a ng u ra n s e r t a meningkatnya a ngka kriminalitas, oleh karena itu pemberantasannya harus mendapat perhatian dan keseriusan dari semua pihak. Bagi pegawai negeri yang dijatuhi hukuman pidana korupsi akan berdampak diberhentikan secara tidak hormat karena sesuai dengan peraturan perundangundangan yang berlaku. Terhadap pegawai negeri yang lain akan berdampak positif dan negatif. Dampak positifnya adalah pegawai negeri yang sedang menjalankan tugas administrasi akan lebih berhatihati jangan sampai terjadi tindakan korupsi bahkan jangan sampai berpikiran untuk melakukan korupsi. Dampak negatifnya adalah pegawai negeri tersebut ketakutan untuk melakukan tugas administrasi negara dan bahkan ada yang berkeinginan untuk menolaknya, oleh karena itu harus ada pendampingan bidang hukum dalam menjalankan tugas administrasi negara.

\section{DAFTAR PUSTAKA}

Dwiputrianti, Septiana, Memahami Strategi Pemberantasan Korupsi di Indonesia, Jurnal Administrasi STIA LAN, Bandung, Vol: VI, No. 3. 2009.

Hamzah A, Pemberantasan Korupsi, Raja grafindo Persada, Jakarta, 2005.

Hartono C.F.G. Sunaryati, Penelitan Hukum di Indonesia Pada Abad ke-20, Alumni, Bandung 1994.

Keban Yaremis, Enam Dimensi Strategi Administrasi Publik : Konsep, Teori dan Isu, Gama Media, Jakarta, 2004.

Kristiadi JB, Administrasi/Manajemen Pembangunan, LAN, Jakarta, 1994.

Kuntjoro DH, Hukum Administrasi Negara, Galia Indonesia, Jakarta, 2004. 
Muchsin, Kekuasaan Kehakiman Yang Merdeka \& Kebijakan Asasi, STIH “IBLAM" Jakarta, 2004.

Muchsin, Kekuasaan Kehakiman Yang Merdeka (Independece Judiciary), UNTAG Press Surabaya, 2010.

Nasucha Chaizi, Reformas $i$ Adminirtrasi Publik : Teori dan Praktek, Grasindo, Jakarta, 2004.

Pasalong Harbani, Teori Administrasi Publik, Alfabeta, Bandung, 2007.

Santoso Priyo Budi, Birokrasi Pemerintahan Orde Baru Perspektif Kultur dan Struktural, Grafindo Persada, Jakarta, 1997.

Soemodihardjo R Djatmiko, Mencegah dan Memberantas Korupsi, Mencermati Dinamika di Indonesia, Prestasi Pustaka Publiser, Jakarta, 2008.

Sudarsono, Kamus Hukum, Rineka Cipta, Jakarat, 2002.

Sunarno, Siswanto, Hukum Pemerintahan Daerah di Indonesia, Sinar Grafika, Jakarta, 2008.

Tidjasutiasna Ating, Adminstrasi Kantor, Armico, Bandung, 1999.

Tutik Titik Triwulan, Pengantar Hukum Tata Usaha Negera Indonesia, Prestasi Pustaka,
Jakarta, 2010.

Wiyono Eko Hadi, Kamus Bahasa Indonesia Lengkap, Palanta, Jakarta, 2007.

Peraturan Perundang-Undangan

Undang-Undang Dasar Republik Indonesia Tahun 1945.

Undang-Undang Nomor 25 Tahun 2009 , tentang Pelayanan Publik.

Undang-Undang Nomor 46 Tahun 2009, tentang Tindak Pidana Korupsi (TIPIKOR)

Undang-Undang Nomor 7 Tahun 2006, tentang Pengesahan United Nations Convention Against Corruption 2003, (Konvensi Perserikatan Bangsa-Bangsa Anti Korupsi, 2002)

Undang-Undang Nomor 32 Tahun 2004, tentang Pemerintahan Daerah.

Undang-Undang Nomor 20 Tahun 2001, tentang Perubahan Atas Undang-Undang Nomor 31 Tahun 1999 , tentang Pemberantasan Tindak Pidana Korupsi.

Undang-Undang Nomor 43 Tahun 1999, tetang Perubahan atas Undang-Undang Nomor 8 Tahun 1974, tentang PokokPokok Kepegawaian.

Undang-Undang Nomor 28 Tahun 1999, tentang Penyelenggaraan Pemerintahan yang Bersih dari Korupsi, Kolisi dan Nepotisme. 
Undang-Undang Nomor 5 Tahun 1986, tentang Pengadilan Tata Usaha Negara.

Peraturan Presiden Republik Indonesia Nomor 65 Tahun 2006, tentang Perubahan Atas Peraturan Presiden Republik Indonesia Nomor 36 Tahun 2005, tentang Pengadaan Tanah bagi P e mbangunan untuk Kepentingan Umum.

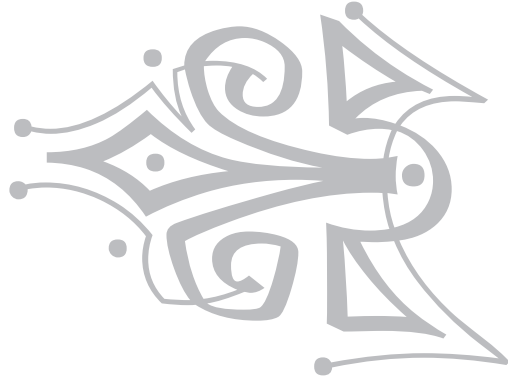

